\title{
DAYA TERIMA DAN KANDUNGAN GIZI DIM SUM YANG DISUBSTITUSI IKAN PATIN (Pangasius Sp.) DAN PURE KELOR (Moringa oleifera) SEBAGAI SNACK BALITA
}

\author{
Acceptance and Nutrient Values of Dim Sum Substituted by Patin Fish (Pangasius sp.) and \\ Moringa Puree (Moringa oleifera) as Snack for Under Five Children \\ Ni Putu Ardhanareswari ${ }^{1^{*}}$ \\ ${ }^{1}$ Program Studi S1 Ilmu Gizi Fakultas Kesehatan Masyarakat, Universitas Airlangga, Surabaya, Indonesia \\ *E-mail: sandrardha@gmail.com
}

\begin{abstract}
ABSTRAK
Usia balita merupakan masa keemasan dimana pertumbuhan dan perkembangan terjadi dengan pesat, oleh karena itu dukungan gizi menjadi sangat penting. Ikan patin dan daun kelor merupakan bahan makanan yang tinggi energi dan protein yang dibutuhkan untuk pertumbuhan balita. Tujuan dari penelitian ini menganalisis pengaruh substitusi ikan patin (Pangasius sp.) dan pure daun kelor (Moringa oleifera) terhadap daya terima dan nilai gizi (energi, dan protein) dim sum sebagai snack sehat bagi balita. Penelitian ini menggunakan metode eksperimental dengan rancangan acak lengkap. Panelis tidak terlatih pada penelitian ini adalah 30 pasang balita dan ibu di Posyandu Kartini 5D untuk menilai kesukaan terhadap warna, rasa, aroma, dan tekstur pada dim sum. Formula kulit dim sum yaitu F0 ( $0 \%$ tepung kelor) sedangkan F1, F2, dan F3 (4\% tepung kelor, 96\% tepung terigu). Formula isi dim sum yaitu F0 (100\% ikan tenggiri), F1 (100\% ikan patin, $0 \%$ daun kelor segar), F2 (90\% ikan patin, 10\% daun kelor segar), F3 (85\% ikan patin, $15 \%$ daun kelor segar). Uji statistik Kruskal Wallis terhadap aroma, rasa, dan warna menunjukkan tidak ada perbedaan signifikan ( $p>0,05)$, sedangkan untuk tekstur terdapat perbedaan signifikan $(\mathrm{p}<0,037)$. Uji lanjutan Mann Whitney terhadap tekstur, menunjukkan tekstur formula kontrol dan formula modifikasi memiliki perbedaan signifikan $(\mathrm{p}<0,05)$, namun hasil uji tekstur antar formula modifikasi tidak menunjukan perbedaan signifikan ( $p>0,05)$. Formula F2 merupakan formula terbaik yang dapat diterima dari segi warna, rasa, aroma dan tekstur, dengan nilai energi sebesar $234 \mathrm{Kkal}$, dan protein sebesar 7,9 g/100 g dim sum.
\end{abstract}

Kata kunci: balita, dim sum, ikan patin, kelor

\begin{abstract}
Under five age is golden period where growth and development occurs rapidly, therefore nutrition support are important. Patin fish and Moringa leaves are foods that high in energy, and protein, which are needed in children's growth. The purpose of this study was to analyze the influence of Patin fish (Pangasius sp.) and Moringa leaves puree (Moringa oleifera) substitution toward the acceptance and nutrient content (energy and protein) of dim sum as healthy snack for under five children. This was a true experimental study with completely randomized design. Untrained panelists in this study were 30 pairs of mother and their children at integrated health post Kartini 5D to assess the acceptance of color, taste, flavor, and texture of dim sum. Dim sum wrappers formula was F0 (0\% Moringa flour) while F1, F2, and F3 (4\% Moringa flour, 96\% wheat flour). Formula for dim sum filling was F0 (100\% Spanish mackerel), F1 (100\% patin fish, $0 \%$ fresh moringa leaves), F2 (90\% patin fish, 10\% fresh moringa leaves), and $F 3$ (85\% patin fish, $15 \%$ fresh moringa leaves). Kruskal Wallis test result on flavor, taste, and color showed no significant difference among all dim sum formulas ( $p>0.05)$, while for texture there was a significant difference $(p<0.037)$. Mann Whitney test showed that texture in control formula and modification formula have significant differences ( $p<0.05)$, but result the test among modification formulas had no significant difference. ( $p>0.05)$. Formula $F 2$ was the best formula that can be accepted in terms of color, taste, flavor, and texture with energy value $234 \mathrm{kcal}$, and protein $7.9 \mathrm{~g} / 100 \mathrm{~g} \mathrm{dim} \mathrm{sum}$.
\end{abstract}

Keyword: under five children, dim sum, patin fish, moringa

(C2019. The formal legal provisions for access to digital articles of this electronic journal are subject to the terms of the Creative CommonsAttribution-NonCommercial-ShareAlike license (CC BY-NC-SA 4.0).Received 10-10-2017, Accepted 16-01-2018, Published online 01-07-2019 


\section{PENDAHULUAN}

Kelompok penduduk bawah usia lima tahun (balita) memiliki peranan penting dalam pembangunan suatu bangsa, mengingat kualitas bangsa dapat diukur salah satunya dari status gizi penduduknya. Jumlah penduduk anak balita di Indonesia lebih dari 30\% sehingga status gizinya perlu diperhatikan (BPS 2010 dalam Marliyati et al., 2014). Masa balita merupakan masa keemasan sekaligus masa yang kritis karena balita rentan mengalami gizi kurang.

Hasil Riskesdas tahun 2013 melaporkan bahwa prevalensi gizi kurang di Indonesia mengalami peningkatan dari tahun 2007 sampai dengan tahun 2013 sebesar $0,9 \%$. Pada tahun 2007 sampai 2010 persentase gizi kurang tetap sebesar $13,0 \%$, kemudian naik $0,9 \%$ pada tahun 2013 menjadi 13,9\%. Hasil Riskesdas tahun 2010 menjelaskan bahwa $24,4 \%$ balita umur 1-3 tahun mengonsumsi makanan di bawah angka kecukupan gizi (AKG).

Pemberian makanan balita yang padat gizi adalah program perbaikan gizi keluarga untuk meningkatkan derajat kesehatan balita (Dinkes Sumenep, 2015). Makanan tambahan dapat berasal dari sumber protein hewani dan nabati, sayur, buah yang mencakup pangan lokal (Kemenkes RI, 2012).

Zat gizi yang penting dalam pertumbuhan balita adalah protein. Fungsi dari protein yang tidak dapat digantikan oleh zat gizi lain, adalah memelihara jaringan tubuh dan memperbaiki jaringan yang rusak (Almatsier, 2011). Bayi dan balita memiliki kebutuhan zat gizi yang relatif lebih besar dibandingkan orang dewasa karena bayi dan balita dalam masa pertumbuhan yang pesat (Palupi, 2014). Sumber protein dapat diperoleh dari makanan hewani maupun nabati, diantaranya adalah ikan patin dan daun kelor.

Ikan Patin (Pangasius sp) merupakan ikan air tawar yang umum dikonsumsi oleh masyarakat Indonesia. Kandungan protein per 100 gram ikan patin adalah 17\% (Marsuci dan Yusuf, 2012)

Ikan patin mengandung asam amino lisin yang tinggi, sedangkan daun kelor tinggi asam amino leusin, valin, serta fenilalanin, sehingga apabila digabungkan dapat mengaktifkan hormon pertumbuhan Human Growth Hormon (HGH). Hormon HGH bertanggung jawab untuk meningkatkan massa otot, membakar lemak, serta mengatur sistem imun (Fernandez, 2014). Daun kelor dikenal dengan superfood yang dapat mencegah malnutrisi (Koul dan Chase, 2015). Kandungan protein daun kelor serbuk, sebesar 27,1 gram per 100 gram bahan (Krisnadi, 2015).

Kualitas cerna protein pada daun kelor setara dengan susu dan telur (Devendra et al., 2011). Hal ini sejalan dengan penelitian Moyo, et al (2011) yang menyebutkan kualitas protein daun kelor mudah dicerna karena dipengaruhi oleh kualitas dan variasi asam amino pada daun kelor. Pengolahan ikan patin selama ini masih terbatas pada pengolahan dengan digoreng, maupun ditumis, sedangkan untuk daun kelor terbatas pada pengolahan sayur bening, sehingga perlu dilakukan pengolahan yang lebih variasi dan menarik untuk balita. Salah satu contohnya adalah dim sum. Dim sum merupakan makanan dari daerah Tiongkok yang cukup populer di Indonesia. Dim sum disajikan dalam bentuk snack berukuran kecil, baik dengan cara dikukus maupun digoreng, dan biasanya disajikan bersama dengan teh (Kah, 2014). Dim sum apabila dikukus memiliki tekstur yang lembut, dan apabila digoreng memberikan tekstur yang renyah, sehingga dim sum cocok untuk dikonsumsi oleh balita karena dapat diolah sesuai selera. Pembuatan dim sum berbahan baku ikan patin dengan substitusi daun kelor dapat menjadi alternatif makanan tambahan (snack) bagi balita. Oleh karena itu, penelitian ini bertujuan untuk menganalisis pengaruh substitusi ikan patin dan pure daun kelor terhadap daya terima dan nilai gizi konsumsi sebagai snack sehat bagi balita.

\section{METODE}

Penelitian ini merupakan eksperimental murni dengan rancangan acak lengkap. Formula pada penelitian ini terdiri dari formula kulit dim sum dan formula isi dim sum. Formula kulit dim sum F0 ( $0 \%$ tepung kelor) sedangkan F1, F2, dan F3 ( $4 \%$ tepung kelor, $96 \%$ tepung terigu). Formula isi dim sum yaitu F0 (100\% ikan tenggiri, 0\% kelor segar), F1 (100\% ikan patin, $0 \%$ daun kelor segar), F2 (90\% ikan patin, 10\% daun kelor segar), dan F3 ( $85 \%$ ikan patin, $15 \%$ daun kelor segar). Penelitian ini berlangsung pada bulan Mei-Agustus 2017.

Pembuatan dim sum dilakukan di Laboratorium pengolahan pangan, Fakultas Kesehatan Masyarakat, 
Universitas Airlangga. Panelis yang melakukan penilaian adalah panelis tidak terlatih yang terdiri dari 30 ibu dan balita dari posyandu Kartini 5D. Panelis tidak terlatih menilai rasa, aroma, tekstur, serta warna dim sum (kulit dan isi). Nilai gizi (energi dan protein) dihitung menggunakan TKPI (Tabel Komposisi Pangan Indonesia). Daya terima panelis diambil dan didata menggunakan angket kesukaan yang yaitu meliputi aroma, rasa, warna, dan tekstur formula dim sum. Data daya terima panelis terbatas dianalisis menggunakan Kruskall Wallis test dan untuk uji lanjutan menggunakan Mann Whitney Test.

Tabel 1. Formula Dim Sum Subtitusi Ikan Patin dan Daun kelor

\begin{tabular}{lrrrr}
\hline \multicolumn{1}{c}{ Bahan } & F0 & F1 & F2 & F3 \\
\hline Bahan Kulit & & & & \\
$\quad$ Tepung terigu (g) & 20 & 17 & 17 & 17 \\
Tepung daun kelor (g) & 0 & 3 & 3 & 3 \\
Kuning telur (g) & 15 & 15 & 15 & 15 \\
Air panas (ml) & 10 & 10 & 10 & 10 \\
Bahan Isi & & & & \\
Ikan tenggiri (g) & 100 & 0 & 0 & 0 \\
Ikan patin (g) & 0 & 100 & 90 & 85 \\
Daun kelor segar (g) & 0 & 0 & 10 & 15 \\
Telur (g) & 60 & 60 & 60 & 60 \\
Tepung sagu (g) & 30 & 30 & 30 & 30 \\
Gula (g) & 3 & 3 & 3 & 3 \\
Merica (g) & 2 & 2 & 2 & 2 \\
Saus tiram (g) & 5 & 5 & 5 & 5 \\
Minyak wijen (g) & 5 & 5 & 5 & 5 \\
Bawang Putih (g) & 7 & 7 & 7 & 7 \\
Garam (g) & 3 & 3 & 3 & 3 \\
\hline
\end{tabular}

Formula dengan daya terima terbaik kemudian energi dan nilai proteinnya diuji di laboratorium gizi. Nilai energi diukur dengan cara menjumlahkan kadar karbohidrat (metode iodometri), kadar lemak (metode Soxhlet) dan kadar protein (metode Kjehdal). Penelitian ini telah mendapatkan persetujuan etik dengan nomor 270-KEPK dari Fakultas Kesehatan Masyarakat.

\section{HASIL DAN PEMBAHASAN}

Penilaian daya terima dim sum secara keseluruhan (kulit dan isi dim sum) oleh panelis tidak terlatih (ibu dan balita) di posyandu Kartini 5D menunjukkan tidak ada perbedaan yang signifikan dari segi warna, aroma, rasa, serta tekstur dim sum. Penilaian warna formula kontrol (F0) memiliki mean rank 3,13 sebesar $73,3 \%$ panelis menyatakan suka dan $20 \%$ panelis menyatakan sangat suka pada warna dim sum. Formula F0 memiliki nilai daya terima tertinggi. Sedangkan untuk formula modifikasi dengan nilai tertinggi adalah formula F2 dengan mean rank sebesar 3,07 (70\%) menyatakan suka pada warna dim sum hijau muda kecoklatan.

Mutu pangan yang dinilai salah satunya adalah warna. Warna pada makanan adalah atribut pertama yang akan dilihat oleh konsumen (Hardjanti, 2008). Warna hijau kecoklatan pada dim sum disebabkan oleh pigmen klorofil dan reaksi maillard. Menurut Krisnadi (2015) kandungan pigmen klorofil tepung daun kelor adalah $162 \mathrm{mg}$ per 8 gram bahan. Hal tersebut sejalan dengan penelitian Tejas, et al (2012) bahwa tepung daun kelor mengandung klorofil $4 \mathrm{x}$ lebih banyak dari rumput gandum (wheat grass) yang dikenal kaya antioksidan. Semakin tinggi proporsi daun kelor, maka warna isi dim sum akan semakin gelap. Hal ini karena zat klorofil teroksidasi menjadi feofitin yang menyebabkan warna menjadi tidak cerah (Priyanto dan Nisa, 2016). Warna coklat pada kulit dim sum disebabkan reaksi maillard pada kulit dim sum. Hal ini dipengaruhi oleh bahan dasar kulit dim sum, yaitu tepung terigu yang apabila digoreng akan menimbulkan warna kecoklatan. Saat suhu tinggi mencapai $100^{\circ} \mathrm{C}$ gugus amino ataupun gugus hidroksil pada peptida di dalam tepung terigu membentuk polimer nitrogen yang akan menghasilkan warna coklat pada dim sum (Priyanto dan Nisa, 2016). Hasil uji statistik Kruskal Wallis, menunjukkan bahwa tidak ada perbedaan warna yang signifikan antar formula ( $\mathrm{p}>0,05)$.

Aroma merupakan atribut yang perlu diperhatikan karena mempengaruhi kesukaan panelis pada dim sum. Aroma yang diharapkan pada dim sum yaitu aroma ikan sesuai bahan yang digunakan dalam dim sum. Pada Tabel 2 menunjukkan tingkat kesukaan aroma tertinggi pada formula F2 dengan mean rank 3,30 yaitu sebanyak 56,7 panelis menyatakan suka terhadap aroma dim sum modifikasi. Aroma pada formula F2 disukai karena tidak terlalu amis dan tidak langu daun kelor. Menurut Supirman, et al (2013) Aroma amis ikan ditimbulkan karena protein pada ikan yang tinggi serta oksidasi dari asam lemak. Di dalam bahan makanan, terdapat zat 

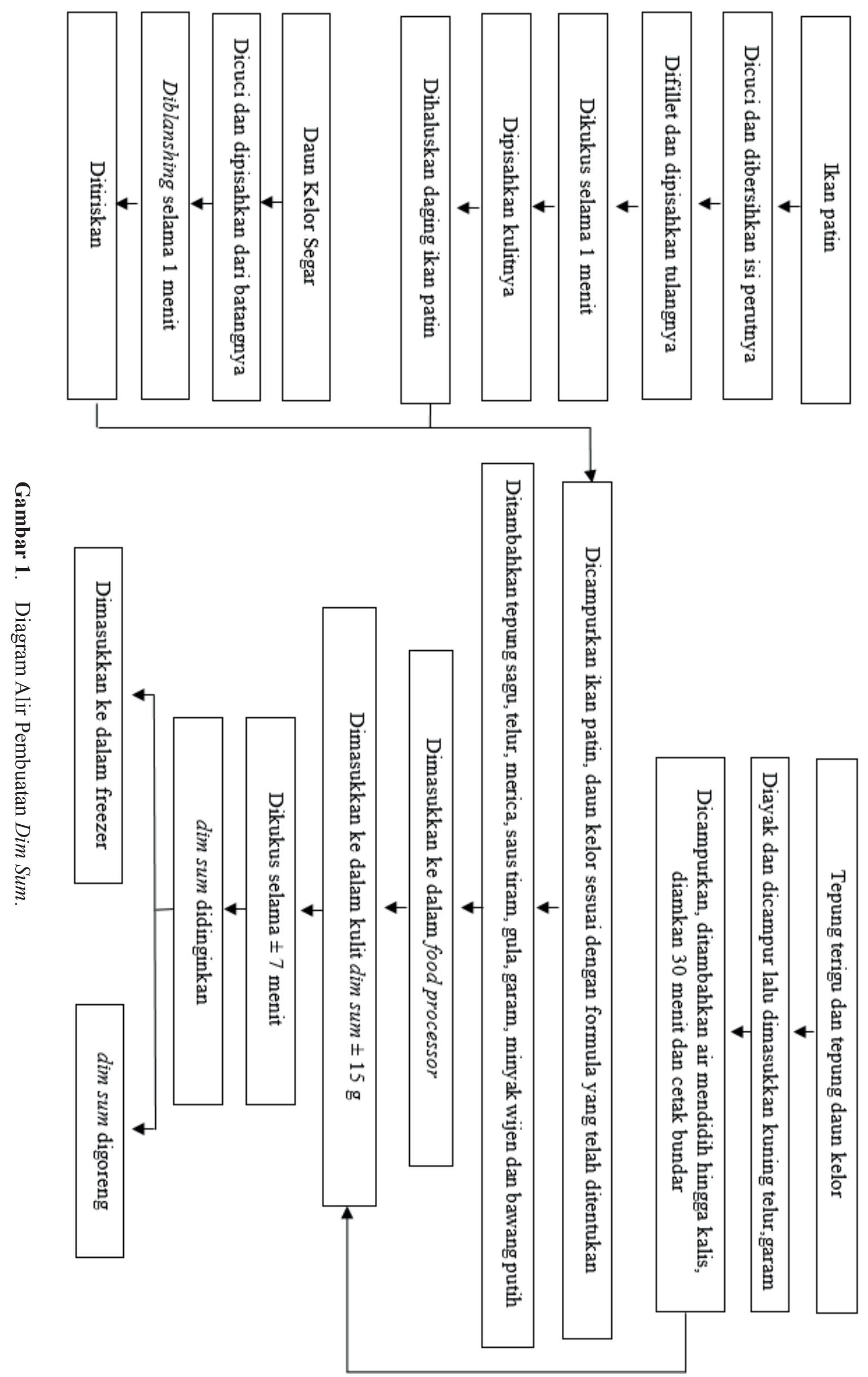
yang bersifat mudah menguap (volatile), yang akan menyebabkan terbentuknya aroma. Zat tersebut diantaranya protein dan lemak. Jika terjadi pemanasan, maka asam amino di dalam protein akan tergradasi dan lemak akan teroksidasi, sehingga bahan aktif kedua zat tersebut terurai, dan menimbulkan aroma (Mutiara et al., 2012).

Substitusi daun kelor pada formulasi isi $\mathrm{dim}$ sum memberikan aroma langu. Menurut Ulfa dan Ismawati (2016) aroma langu daun kelor disebabkan karena daun kelor mengandung enzim lipoksidase dan minyak atsiri. Di dalam sayuran hijau terdapat enzim lipoksidase yang apabila tidak melalui pemasakan dengan cara yang benar, maka akan menimbulkan aroma langu yang tidak disukai panelis. Cara meminimalisir aroma langu adalah dengan merendam di air es atau merebus dengan air garam (Andawulan, 2011). Pada penelitian ini dilakukan pre treatment blanching daun kelor selama 1 menit. Hasil uji Kruskall Wallis pada aroma menunjukkan nilai $\mathrm{p}>0,05$, artinya tidak ada perbedaan signifikan dari semua formula.

Tekstur pada pembuatan formula dim sum ikan patin dan daun kelor adalah renyah. Tekstur renyah dihasilkan dari kandungan gluten pada kulit dim sum. Sifat dari gluten adalah menyerap air. Bahan makanan apabila mengandung gluten yang cukup tinggi, maka kemampuan gluten untuk menyerap air juga semakin tinggi, oleh karena itu kandungan air dalam permukaan bahan akan menjadi rendah, dan membentuk teksur renyah (Pangaribuan, 2013).

Tabel 2 menunjukkan tekstur dim sum terbaik adalah F0 (formula kontrol) yang disukai oleh panelis sebanyak 53,3\%. Formula modifikasi F2 merupakan formula modifikasi dengan nilai mean rank tertinggi $(3,07)$. Tekstur dim sum selain dipengaruhi oleh kulit, juga dipengaruhi oleh isian dim sum. Pada formula modifikasi F1 sampai F3, proporsi ikan patin yang digunakan semakin sedikit, sehingga mempengaruhi tekstur dim sum.

Daging ikan patin maupun ikan tenggiri memiliki struktur serabut yang pendek, terputus dan tidak kompak. Saat dim sum digoreng maka tekstur akan menjadi kompak dan menyatu karena minyak terserap ke dalam daging ikan (Alhana et al., 2011). Tekstur dari pure daun kelor lebih kasar karena terdapat kandungan serat, yang apabila semakin tinggi proporsi daun

Tabel 2. Distribusi Tingkat Kesukaan Panelis terhadap Mutu Organoleptik Dim sum

\begin{tabular}{|c|c|c|c|c|c|c|c|c|c|c|c|c|}
\hline \multirow{2}{*}{ Formula } & \multicolumn{2}{|c|}{ Sangat tidak suka } & \multicolumn{2}{|c|}{ Tidak suka } & \multicolumn{2}{|c|}{ Suka } & \multicolumn{2}{|c|}{ Sangat suka } & \multicolumn{2}{|c|}{ Total } & \multirow{2}{*}{$\begin{array}{c}\text { Mean } \\
\text { Rank }\end{array}$} & \multirow[t]{2}{*}{ p-value } \\
\hline & $\mathrm{n}$ & $\%$ & $\mathrm{n}$ & $\%$ & $\mathrm{n}$ & $\%$ & $\mathrm{n}$ & $\%$ & $\mathrm{n}$ & $\%$ & & \\
\hline \multicolumn{13}{|l|}{ Tektur } \\
\hline F0 & 0 & 0 & 3 & 10,0 & 16 & 53,3 & 11 & 36,7 & 30 & 100 & 3,7 & \multirow{4}{*}{$0,037^{*}$} \\
\hline $\mathrm{F} 1$ & 0 & 0 & 8 & 26,7 & 19 & 63,3 & 3 & 10,0 & 30 & 100 & 2,8 & \\
\hline $\mathrm{F} 2$ & 0 & 0 & 6 & 20,0 & 16 & 53,3 & 8 & 26,7 & 30 & 100 & 3,7 & \\
\hline F3 & 0 & 0 & 8 & 26,7 & 18 & 60,0 & 4 & 13,3 & 30 & 100 & 2,9 & \\
\hline \multicolumn{13}{|l|}{ Aroma } \\
\hline F0 & 0 & 0 & 3 & 10,0 & 22 & 73,3 & 5 & 16,7 & 30 & 100 & 3,7 & \multirow{4}{*}{0,352} \\
\hline $\mathrm{F} 1$ & 0 & 0 & 3 & 10,0 & 20 & 66,7 & 7 & 23,3 & 30 & 100 & 3,1 & \\
\hline $\mathrm{F} 2$ & 0 & 0 & 2 & 6,7 & 17 & 56,7 & 11 & 36,7 & 30 & 100 & 3,3 & \\
\hline F3 & 0 & 0 & 3 & 10,0 & 21 & 70,0 & 6 & 20,0 & 30 & 100 & 3,1 & \\
\hline \multicolumn{13}{|l|}{ Rasa } \\
\hline F0 & 0 & 0 & 1 & 3,3 & 21 & 70,0 & 8 & 26,7 & 30 & 100 & 3,2 & \multirow{4}{*}{0,530} \\
\hline $\mathrm{F} 1$ & 0 & 0 & 6 & 20,0 & 18 & 60,0 & 6 & 20,0 & 30 & 100 & 3,0 & \\
\hline F2 & 0 & 0 & 4 & 13,3 & 16 & 53,3 & 10 & 33,3 & 30 & 100 & 3,2 & \\
\hline F3 & 0 & 0 & 6 & 20,0 & 17 & 56,7 & 7 & 23,3 & 30 & 100 & 2,3 & \\
\hline \multicolumn{13}{|l|}{ Warna } \\
\hline F0 & 0 & 0 & 2 & 6,7 & 22 & 73,3 & 6 & 20,0 & 30 & 100 & 3,1 & \multirow{4}{*}{0,264} \\
\hline $\mathrm{F} 1$ & 0 & 0 & 5 & 16,7 & 23 & 76,7 & 2 & 6,7 & 30 & 100 & 2,9 & \\
\hline F2 & 0 & 0 & 3 & 10,0 & 21 & 70,0 & 6 & 20,0 & 30 & 100 & 3,1 & \\
\hline F3 & 1 & 3.3 & 4 & 13,3 & 21 & 70,0 & 4 & 13,3 & 30 & 100 & 2,9 & \\
\hline
\end{tabular}

Ket: * berbeda signifikan $(\mathrm{p}<0,05)$ 


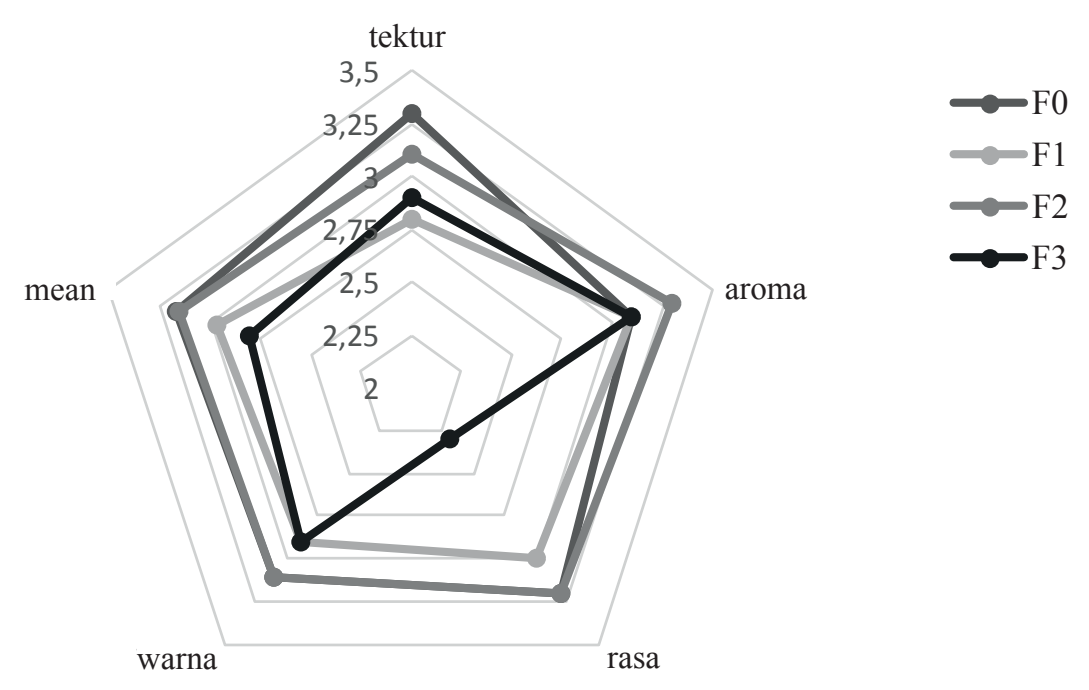

Gambar 2. Tingkat Kesukaan Panelis pada Dim sum.

kelornya pada dim sum maka tekstur isi dim sum akan semakin tidak kompak.

Hasil dari uji statistik Kruskal Wallis menunjukkan nilai $\mathrm{p}<0,05$ sehingga terdapat perbedaan daya terima tekstur yang signifikan. Uji lanjutan Mann Whitney menunjukkan terdapat perbedaan signifikan tekstur formula dim sum kontrol (F0) dengan formula dim sum modifikasi (F1, F2, F3), sedangkan antar formula modifikasi tidak menunjukkan adanya perbedaan tekstur yang signifikan.

Pada variabel rasa, panelis menilai rasa dim sum yang dihasilkan adalah gurih. Rasa gurih yang dominan dari ikan terdapat pada formula kontrol (F0) dan pada F1 karena pada formula F1 hanya bagian kulit saja yang dimodifikasi, sedangkan isiannya tanpa substitusi pure kelor. Pada formula F2 dan F3 memberikan rasa gurih dan ada sedikit rasa kelor. Rasa gurih terbentuk karena adanya asam glutamate yang secara alami terdapat pada bahan makanan protein tinggi, seperti ikan (Thariq et al., 2014)

Pada Tabel 2 dapat dilihat mean rank dari formula kontrol dan formula F2 memiliki nilai yang berbeda tipis yaitu 3,23 dan 3,20. Substitusi daun kelor terhadap ikan patin sebanyak $10 \mathrm{~g}$ memberikan rasa gurih dan rasa daun kelor yang disukai panelis. Pada formula F3 substitusi daun kelor sebanyak $15 \mathrm{~g}$ memberikan rasa daun kelor yang dominan cenderung agak sepat.

Rasa sepat disebabkan daun kelor memiliki kandungan tannin. Saat zat tannin masuk ke dalam mulut, terjadi penggumpalan protein di dalam mukosa rongga mulut, sehingga terbentuk rasa yang kurang disukai panelis (Muchtadi et al., 2010). Hasil uji kruskal wallis pada karakteristik rasa menunjukkan nilai $\mathrm{p}>0,05$ sehingga tidak ada perbedaan yang signifikan dari semua formula.

Hasil uji statistik Kruskal Wallis daya terima dim sum menunjukkan tidak ada perbedaan yang signifikan pada karakteristik warna, rasa, dan aroma. Akan tetapi, terdapat perbedaan signifikan pada tekstur dim sum $(p<0,05)$. Uji lanjutan Mann Whitney pada tekstur menunjukkan perbedaan signifikan pada F0 dengan F1, F2, dan F3. Sedangkan formula modifikasi F1, F2, F3 tidak memiliki perbedaan yang signifikan $(>, 05)$.

Formula modifikasi dim sum yang memiliki daya terima tertinggi adalah F2 dengan komposisi kulit dim sum $17 \mathrm{~g}$ tepung terigu, $3 \mathrm{~g}$ tepung daun kelor dan isi dim sum $90 \mathrm{~g}$ ikan patin, $10 \mathrm{~g}$ pure kelor, $30 \mathrm{~g}$ tepung sagu.

Daya terima meliputi penilaian panelis atau seseorang terhadap suatu kualitas makanan sehingga timbul respon suka atau tidak menyukai makanan tersebut (Soewarno, 1985). Penilaian tingkat kesukaan panelis dinyatakan dalam tingkatan sangat tidak suka, tidak suka, suka, dan sangat suka. Pada Gambar 1 dapat dilihat bahwa formula F2 memiliki tingkat kesukaan yang mirip dengan $\mathrm{F} 0$ dari segi warna, rasa, aroma, dan terkstur. Formula F2 dapat diterima oleh panelis karena memiliki rasa yang tidak terlalu amis maupun sepat, aroma yang tidak langu, tekstur 
yang renyah serta warna yang disukai panelis. Panelis cenderung menyukai rasa yang balance, dalam arti bahan satu dengan bahan lainnya dalam suatu produk makanan tidak saling mendominasi (Azizah, 2015).

Atribut lain yang perlu diperhatikan dalam membuat formulasi makanan adalah nilai gizi serta kecukupannya saat dikonsumsi oleh balita yang dihitung sesuai dengan Angka Kecukupan Gizi (AKG) 2013. Dim sum yang disajikan berupa snack (makanan selingan) yang menyumbang 10$15 \%$ energi dan protein dari kebutuhan total balita. Kebutuhan 10-15\% energi balita apabila dihitung sekitar 113-169 kkal dan protein sekitar 2,6-3,9 gram.

Nilai gizi energi dan protein pada formulasi dihitung berdasarkan Tabel Komposisi Pangan Inonesia (TKPI). Pada tabel 3 dapat dilihat perbandingan perhitungan berdasarkan TKPI dan dari hasil laboratorium. Dari perhitungan tabel diatas dapat diketahui apabila balita mengonsumsi 50 gram dim sum (3-4 buah) maka kebutuhan 10$15 \%$ kebutuhan energi dan protein balita dapat terpenuhi. Nilai gizi pengujian laboratorium menunjukkan penurunan nilai energi dari 265 kkal menjadi 234 kkal dan protein dari 12,1 gram menjadi 7,9 gram.

Tabel 3. Distribusi Nilai Energi dan Protein per 100 gram Dim Sum

\begin{tabular}{ccccc}
\hline \multirow{2}{*}{ Formula } & \multicolumn{2}{c}{ Kadar Energi (kkal) } & \multicolumn{2}{c}{ Kadar Protein (gram) } \\
\cline { 2 - 5 } & TKPI & Laboratorium & TKPI & Laboratorium \\
\hline F0 & 267 & - & 13,3 & - \\
F1 & 267 & - & 12,2 & - \\
F2 & 265 & 23,4 & 12,1 & 7,9 \\
F3 & 264 & - & 11,9 & - \\
\hline
\end{tabular}

(-): tidak dianalisis laboratorium

Hal ini disebabkan ketelitian uji laboratorium lebih tinggi dibandingkan dengan hasil perhitungan TKPI. Data pada perhitungan TKPI menggunakan bahan makanan yang telah ditentukan, sedangkan bahan makanan yang digunakan pada formulasi dim sum ini dapat berbeda kandungan gizinya meskipun bahan yang digunakan adalah sama.

Kandungan energi formula F0 dari perhitungan TKPI lebih tinggi dari formula modifikasi karena nilai energi ikan tenggiri lebih tinggi dibandingkan energi ikan patin dan daun kelor, sehingga apabila di substitusi maka akan terjadi penurunan nilai energi. Kandungan protein pada tabel 3 menunjukkan terjadi penurunan hasil laboratorium dibandingkan dengan perhitungan TKPI. Penurunan nilai protein dapat disebabkan cara pengolahan dim sum yang digoreng. Penggorengan bahan makanan yang mengandung protein, menyebabkan proses denaturasi pada protein. Semakin tinggi suhu penggorengan maka semakin besar proses denaturasi yang terjadi, sehingga struktur protein menjadi lebih sederhana (Alhana, 2011).

Disamping itu, proses penggorengan dapat meningkatkan kandungan lemak karena minyak yang terserap ke dalam dim sum. Apabila kandungan lemak meningkat, maka proporsi kandungan zat gizi lain termasuk protein akan menurun secara proporsi.

Penelitian pembuatan dim sum ini dapat digunakan sebagai referensi pemberian healthy snack pada balita, meskipun nilai energi dan protein pada formula modifikasi terbaik (F2) lebih rendah daripada formula kontrol (F0), tetapi penggunaan bahan baku ikan patin dengan pure kelor dapat memberikan nilai ekonomi yang lebih terjangkau dibanding menggunakan bahan baku ikan tenggiri.

\section{KESIMPULAN DAN SARAN}

Formula dim sum dari segi warna, rasa, dan aroma tidak memiliki perbedaan yang signifikan, akan tetapi dari segi tekstur, memiliki perbedaan yang signifikan. Formula F2 dengan komposisi kulit dim sum (17 $\mathrm{g}$ tepung terigu, $3 \mathrm{~g}$ tepung daun kelor) dan isi dim sum (90 g ikan patin, $10 \mathrm{~g}$ pure kelor, $30 \mathrm{~g}$ tepung sagu) merupakan formula modifikasi terbaik.

Disarankan mengonsumsi 3-4 buah dim sum atau setara 50 gram sebagai makanan selingan untuk memenuhi 10-15\% kebutuhan energi dan protein pada balita.

\section{DAFTAR PUSTAKA}

Alhana., J.,Agus M., \& Purnomo, D. (2011). Analisis asam amino dan pengamatan jaringan daging fillet ikan patin (pangasius hypophthalmus) akibat peggorengan (Skripsi, Institut Pertanian Bogor, Indonesia). Retrieved from http:// repository.ipb.ac.id/handle/123456789/53443 
Almatsier, S., Soetarjo, S., \& Soekatri, M. (2011). Gizi seimbang dalam daur kehidupan. Jakarta: PT Gramedia Pustaka Utama.

Andawulan, N. (2011) Analisis pangan. Jakarta: Dian Rakyat

Azizah, A. (2015). Tingkat kerapuhan dan daya terima biskuit yang disubstitusi tepung daun kelor (moringa oleifera). Universitas Muhammadiyah Surakarta. Retrieved from http://eprints.ums.ac.id/38334/1/NASPUB\%20 PERPUSTAKAAN.pdf

Devendra, B, N., Srinivas, N., Prasad, V, S., \& Latha, S. (2011). Antimicrobial activity of moringa oleifera lam., leaf extract against selected bacterial and fungal strains. International Journal of Pharma and Bio Sciences, 2(3), Retrieved from http://www.ijpbs.net/download. php?download_file $=$ vol-2_issue $-3 /$ bio science/2.pdf

Dinas Kelautan dan Perikanan Jawa Timur. (2016). Keragaman konsumsi ikan di beberapa kota di Jawa Timur. Retrieved from http://diskanlut. jatimprov.go.id/?p=2511

Dinas Kesehatan Sumenep. (2015). Pemberian makanan tambahan (pmt) untuk balita. Retrieved from http://www.dinkessumenep. org/2015/06/19/pemberian-makanan-tambahanpmt-untuk-balita/

Direktorat Bina Gizi. (2012). Panduan penyelenggaraan pmt pemulihan bagi balita gizi kurang dan ibu hamil kek. Jakarta: Kementerian Kesehatan

Fernandez, I., 2014. Asam Amino Esensial untuk Tumbuh Kembang Anak. Food for Kids Indonesia Edisi 11 Bulan November 2014 : Semarang.

Hardjanti, S. (2008). Potensi daun katuk sebagai sumber zat pewarna alami dan stabilitasnya selama pengeringan bubuk dengan maltodekstrin. Jurnal Penelitian Saintek Yogyakarta, 13(1), 1-18. doi: 10.21831/jps.v13i1.180

Kementerian Kesehatan Republik Indonesia. (2010). Laporan riset kesehatan dasar (Riskesdas) 2010. Jakarta: Badan Penelitian dan Pengembangan Kesehatan Kementerian Kesehatan RI

Kementerian Kesehatan Republik Indonesia. (2013). laporan riset kesehatan dasar (Riskesdas) 2013. Jakarta: Badan Penelitian dan Pengembangan Kesehatan Kementerian Kesehatan RI

Koul, B. \& Chase, N. (2015). Moringa oleifera lam.: panacea to several maladies. Journal of Chemical and Pharmaceutical Research 7(6), 687-707. Retrieved from http://www.
academia.edu/35030815/Moringa_oleifera Lam._Panacea_to_several_maladies

Krisnadi, A. D. (2015). Kelor super nutrisi. Edisi Revisi Maret 2015. Blora: LSM Mepeling

Marliyati, S. A., Nugraha, A., \& Anwar, F., (2014). Asupan vitamin a, dan status gizi anak sekolah dasar di Kecamatan Leuwiliang, Kabupaten Bogor. Jurnal Gizi dan Pangan, 9(2), 109-116. doi: 10.25182/jgp.2014.9.2.\%25p Retrieved from http://journal.ipb.ac.id/index.php/ jgizipangan/article/view/8729

Marsuci, R., \& Yusuf, N. (2012). Formulasi produk ilabulo ikan patin (Pangasius sp.). Laporan Penelitian Universitas Negeri Gorontalo. Retrieved from http://repository.ung.ac.id/riset/ show/1/226/formulasi-produk-ilabulo-ikanpatin-pangasius-sp.html

Moyo, B. Masika, J. P., Hugo, A \& Muchenje, V. (2011). Nutritional characterization of moringa (Moringa oleifera Lam) leaves. African Journal of Biotechnology, 10(60), 12925-12933. doi: 10.5897/AJB10.1599. Retrieved from https://www.ajol.info/index.php/ajb/article/ view/96497

Muchtadi, T. R, \& Ayustaningwarno. (2010). Teknologi proses pengolahan pangan. Bandung: Alfabeta

Mutiara, E, Adikahriani \& Wahidah, S. (2012). Pengembangan formula biskuit daun katuk untuk meningkatkan asi. Jurnal Fakultas Teknik Universitas Negeri Medan. Retrieved from http://digilib.unimed.ac.id/19945/

$\mathrm{Ng}$ Lip Kah. 2014. Cooking classics dim sum a step by step cookbook. Singapore: Marshall Cavendish Cuisine

Palupi, M., (2014). Pengaruh pemberian mikronutrien (taburia) terhadap asupan makan balita yang menjalani rawat inap di rumah sakit. (Tesis, Universitas Diponegoro, Indonesia). Retrieved from http://eprints.undip. ac.id/43151/

Pangaribuan, A. (2013). Substitusi tepung talas belitung pada pembuatan biskuit daun kelor (Moringa oleifera Lamk). (Skripsi, Program Studi Biologi Universitas Atma Jaya Yogakarta, Indonesia). Retrieved from http://e-journal.uajy. ac.id/4353/

Priyanto, D. A. \& Nisa, C. F. (2016). Formulasi daun kelor dan ampas daun cincau sebagai tepung komposit pada pembuatan mie instan. Jurnal Teknologi Pertanian, 17(1), 29-30. Retrieved from http://jtp.ub.ac.id/index.php/ jtp/article/viewFile/561/891 
Soewarno. (1985). Penilaian organoleptik. Jakarta: PT. Bhratara Karya Aksara

Supirman S. S., Kartikaningsih, H. \& Zaelanie, K. (2013). Pengaruh perbedaan ph perendaman asam jeruk nipis (Citrus auratifolia) dengan pengeringan sinar matahari terhadap kualitas kimia teh alga coklat (Sargassum fillipendula). THPI Student Journal, 1(1), 46-52. Retrieved from http://thpi.studentjournal.ub.ac.id/index. php/thpi/article/view/6

Tejas, H. G., Umang, H. Payal, B. Tusharbindu, D. \& Pravin, T. (2012). A panoramic view on pharmacognostic, pharmacological, nutritional, therapeutic and prophylactic values of moringa oleifera lam. International Research Journal of
Pharmacy. 3(6), 1-7. Retrieved from http://www. irjponline.com/admin/php/uploads/1154 pdf.

Thariq, A, S. Swastawati, F. \& Surti, T. (2014). Pengaruh perbedaan konsentrasi garam pada peda ikan kembung (Rastrelliger neglectus) terhadap kandungan asam glutamat pemberi rasa gurih (Umami). Jurnal Pengolahan dan Bioteknologi Hasil Perikanan, 3(3), 104-111. Retrieved from https://ejournal3.undip.ac.id/ index.php/jpbhp/article/view/5662

Ulfa, S. \& Ismawati, R. (2016). Pengaruh penambahan jumlah dan perlakuan awal daun kelor terhadap sifat organoleptik bakso. E-journal Boga, 5(3). Retrieved from http:// jurnalmahasiswa.unesa.ac.id/index.php/jurnaltata-boga/article/view/16621 